\title{
Two-tiers Consolidation - The New Public Management in Action Marian KACHNIARZ ${ }^{1}$, Zbigniew PIEPIORA ${ }^{2}$ and Piotr ROGALA ${ }^{3}$ \\ 1, 2Wrocław University of Environmental and Life Sciences, Poland \\ ${ }^{3}$ Wrocław University of Economics, Poland
}

Keywords: New public management, Territorial structure reforms, Two- tiers consolidation.

\begin{abstract}
In many countries, they are implemented public sector reforms inspired New Public Management. The main motivation are effectiveness policy, cost reduction and efficiency improvement. They often involve reducing bureaucracy by reducing the number of administrative levels. The main goal of paper is to characterize activities consisting in merging two local government tiers - a city and a county, and an attempt to their evaluate through the prism of results. The paper is based on the analysis of reports from ex-post research of such reforms' effects from many countries worldwide.
\end{abstract}

\section{Introduction}

In the course of the last three decades the trend towards local government units' size increase has been the most commonly applied method of administrative structure reforms in many countries worldwide, regardless of the continent or culture circle. The paper highlights such processes, which in the world literature are referred to as city-county consolidation. The purpose of the article is, firstly, to discuss such processes and, secondly, to evaluate the obtained results, particularly the ones which acted as the main incentives for the reformers.

The article is of review nature - the ex-post analysis of abundant literature, discussing these reforms' objectives and implications, is the primary applied method aimed at achieving the set goals The presented problems were divided into three main parts. The first is an outline of theoretical determinants underlying consolidation reforms. The second one presents the nature and scope of reforms consisting in the consolidation of cities and counties. The third of them discusses the outcomes of reforms which emerge from the world literature review.

\section{Theoretical Determinants of Consolidation Processes}

In the opinion of many economists an extensive fragmentation of structures results in the increased transaction costs of the provided services. In turn, larger unit size allows achieving both economies of scale and economies of scope. Large fragmentation does not allow, for example, effective agglomeration management [1]. In terms of local governments it was described in detail by Dollery, Crase and Johnson [2]. According to this theory the consolidation of entities providing public services should result in the reduction of unit costs and more efficient functioning [3]. Such opinion is based on the approach that larger units are characterized by better allocation of financial, material and human resources [4]. Thus this trend can be referred to as "bigger is better". This conviction is so deep that it frequently takes the form of an undisputable paradigm, which does convince many authors of reforms. The reviews of transformations in the territorial structure of European countries, conducted by Wollmann [5], clearly indicate the adherence to this idea. While the mainstream economists follow the economies of scale approach (both in production and public sector), the e.g. institutionalists and sociologists demonstrate larger distance to such attitude. They accuse economists of having a narrowed down picture of the functioning of public institutions. In fact, however, the limitations, rules of conduct and procedures made up by people are actually responsible for human interactions. Such perspective allows appreciating the role of informal limitations, which remain the component of cultural heritage, the system of ideas and ideologies in a particular society. Every change cau ses effects in the hierarchy of cities [6]. North emphasizes 
that informal rules feature a specific inertia, which causes that the occurring change in formal rules (e.g. law, structures or, in a broader perspective, economic system) does not result in the expected effects [7]. Therefore the reform of local government structures should take the above mentioned determinants into account if the increase in quality of life is its goal [8]. P. Swianiewicz presented an excellent summary of the opposing arguments, i.e. for consolidation and for maintaining more fragmented structures [9].

\section{The Characteristics of Two-tiers Consolidation}

Two- tiers consolidation is a vertical initiative resulting in the elimination of one of the local government tier structures (city-county). Usually it is the higher local government tier, i.e. a county. Its tasks are taken over by the largest municipality, i.e. the county capital. It represents the classical example of unsymmetrical decentralization of tasks within which the same tier units (municipalities) can have a varied range of competencies. Following Anglo-Saxon literature (mainly American) such activities are commonly referred to as city-county consolidation and the units established in this way as two-tier cities. The supporters of such actions highlight the potential possibilities resulting from the reduced number of tiers, which can result in lower costs of administration functioning. Such changes can also increase public orientation in the intricate structures of local administration, since the effect of offices duplication in the same city is eliminated.

Due to the nature of these changes in the countries of strong unitary traditions they can be carried out systemically, simultaneously in all units. For example, such changes were introduced from $1^{\text {st }}$ January 2003 in the Czech Republic. Local government counties were liquidated and the respective tasks were distributed among municipalities and provinces. Some of the municipalities received a special category, i.e. "municipalities with extended competencies", as they were carrying out certain tasks for other municipalities [10]. A similar change was implemented in North Korea - as a result of government's decision from 1995 the consolidation of 49 cities and counties was carried out [11, $12,13]$. A reduced number of municipalities (from 114 to 22) has been functioning in Ireland since 2012, and the reduction process was accompanied by establishing joint administrative areas [14]. In the UK the restructuring processes varied depending on their components. For example, a two-tier local government system in Scotland was given up in 1996 and thus the total number of local government units was reduced from 65 to 32 .

More extensive options exist in federal states, where such changes can be implemented selectively. The most of such reforms were carried out in the United States. The total of over 130 initiatives were undertaken there and about 40 of them resulted in establishing such two-tier local governments. Over a dozen of them were created in the recent 15 years [15]. An extensive action of a two-tier system development was also carried out in Canada. As early as in the 90 s of the $20^{\text {th }}$ century their introduction was initiated in the province of Ontario and after 2003 also in Alberta, British Columbia and Newfoundland. Canadian experiences are, however, slightly different than the American ones. The establishment of a two-tier system was simultaneously accompanied by the horizontal consolidation (consolidation of municipalities). For example, in Ontario, between 1996 and 2002, 566 small municipalities were consolidated and thus 198 new units were established [16].

\section{The Effects of City-county Consolidation}

Many years of experience in carrying out the city-county consolidation reforms resulted in an abundant research output in terms of their effects. It remains a part of the broader research area covering economies of scale in administration. For the purposes of this article it was attempted to analyse the entire available world literature discussing this problem. It should be emphasized that this review does not refer to theoretical and model specific consolidation assumptions, but the substantive ex-post research findings. They carry high potential for future debates on the possible reforms. Part of them takes the form of meta-analyses evaluating several dozens of units and the effects of changes across countries (or states), other are of individual nature representing case 
studies of single consolidations. The results of such review are presented in the form of very synthetic conclusions, whereas all analysed publications (including their authors, year of publication, research subject and simplified conclusions) are presented in table 1 .

Table 1. The list of research findings on the effects of city-county consolidation

\begin{tabular}{|c|c|c|c|}
\hline Year & Authors & Research location & Findings \\
\hline 1992 & Sam Stanley [17] & Indianapolis-Marion County, IN & $\begin{array}{l}\text { economies of scale recorded based on small } \\
\text { units' consolidation }\end{array}$ \\
\hline 2000 & $\begin{array}{l}\text { Allen B. Brierly } \\
{[18]}\end{array}$ & theoretical model & consolidation does not result in cost savings \\
\hline 2000 & $\begin{array}{l}\text { Dan Durning, } \\
\text { Patricia Neobbie } \\
{[19]}\end{array}$ & Athens-Clarke County, GA & $\begin{array}{l}\text { opportunism of employees and costs of } \\
\text { changes outweigh potential benefits }\end{array}$ \\
\hline 2000 & $\begin{array}{l}\text { Suzanne Leland, } \\
\text { Kurt Thurmaier } \\
{[20]}\end{array}$ & Wyandotte County/Kansas City, KS & $\begin{array}{l}\text { benefits from greater administration } \\
\text { transparency; cost reduction not recorded }\end{array}$ \\
\hline 2000 & $\begin{array}{l}\text { Sally Selden, } \\
\text { Richard Campbell } \\
{[21]}\end{array}$ & Athens-Clarke County, GA & $\begin{array}{l}\text { consolidation can result in savings, but only } \\
\text { in small municipalities, outside metropolitan } \\
\text { areas }\end{array}$ \\
\hline 2002 & Sammis White [22] & $\begin{array}{l}\text { Louisville-Jefferson County, KY } \\
\text { and other }\end{array}$ & $\begin{array}{l}\text { there is no evidence that consolidated units } \\
\text { are more economical; higher costs resulting } \\
\text { from "levelling up" }\end{array}$ \\
\hline 2004 & Jered Carr [see 16] & $\begin{array}{l}\text { meta-analysis - review of existing } \\
\text { research }\end{array}$ & $\begin{array}{l}\text { consolidation does not result in cost savings, } \\
\text { it simplifies administrative structure }\end{array}$ \\
\hline 2005 & $\begin{array}{l}\text { Frank Gamrat, Jake } \\
\text { Haulk [23] }\end{array}$ & Louisville-Jefferson County, KY & $\begin{array}{l}\text { the difference in functioning costs is } \\
\text { insignificant }\end{array}$ \\
\hline 2005 & Chris Pineda [24] & $\begin{array}{l}\text { meta-analysis - review of existing } \\
\text { literature }\end{array}$ & $\begin{array}{l}\text { diseconomies of scale in labour-intensive } \\
\text { services; larger bureaucracy resulting from } \\
\text { "levelling up" }\end{array}$ \\
\hline 2006 & John Parr [25] & $\begin{array}{l}\text { Athens-Clarke County, GA and } \\
\text { Louisville-Jefferson County, KY }\end{array}$ & recorded benefits of consolidation \\
\hline 2009 & Beverly Cain [26] & $\begin{array}{l}\text { Louisville-Jefferson County, KY, } \\
\text { Wyandotte County/Kansas City, KS, } \\
\text { Athens-Clarke County, GA, City } \\
\text { and County of Broomfield, CO }\end{array}$ & $\begin{array}{l}\text { consolidation does not result in savings of } \\
\text { functioning costs }\end{array}$ \\
\hline 2010 & $\begin{array}{l}\text { Michael Chisholm } \\
\text { [27] }\end{array}$ & $\begin{array}{l}\text { meta-analysis of English local } \\
\text { governments }\end{array}$ & $\begin{array}{l}\text { merger supporters overestimate savings and } \\
\text { underestimate transition costs }\end{array}$ \\
\hline 2011 & $\begin{array}{l}\text { Marc Holzer, John } \\
\text { Fry [28] }\end{array}$ & $\begin{array}{l}\text { meta-analysis - review of world } \\
\text { research }\end{array}$ & no evidence of lower service provision costs \\
\hline 2012 & Pat Hardy [see 15] & $\begin{array}{l}\text { meta-analysis based on the available } \\
\text { research findings }\end{array}$ & $\begin{array}{l}\text { there is very little evidence of positive } \\
\text { effects of consolidation }\end{array}$ \\
\hline 2013 & $\begin{array}{l}\text { Germa Bel, M. } \\
\text { Warner [29] }\end{array}$ & $\begin{array}{l}\text { analysis of } t w o \text {-tier units in } \\
\text { European countries }\end{array}$ & no clear effects \\
\hline 2014 & $\begin{array}{l}\text { Mark Callanan, } \\
\text { Ronan Murphy, } \\
\text { Aodh Quinlivan } \\
\text { [see 14] }\end{array}$ & $\begin{array}{l}\text { Limerick, Waterford, Tipperary } \\
\text { (IRL) }\end{array}$ & $\begin{array}{l}\text { intuitive opinion that larger units are more } \\
\text { efficient does not apply to Irish local } \\
\text { governments }\end{array}$ \\
\hline 2014 & $\begin{array}{l}\text { Raphael Caprio, } \\
\text { Marc Pfeiffer [30] }\end{array}$ & $\begin{array}{l}\text { counties and municipalities in New } \\
\text { Jersey }\end{array}$ & $\begin{array}{l}\text { larger size is insignificant in terms of costs } \\
\text { and focusing on consolidation effectiveness } \\
\text { is a folk hypothesis }\end{array}$ \\
\hline
\end{tabular}

Source: author's compilation.

The surprising effect of the aforementioned analyses is the absence of any conclusive confirmation of the seemingly sensible opinion that large units are more efficient. The researchers agree that the experience gained in consolidating local government tiers suggests that savings are not guaranteed and their planned level is most often missed. It is a standard, however, not to recognize both costs and time spent on their consolidation. Therefore, the aspects which according to reform drafts are supposed to result in significant savings, after their implementation frequently bring about higher costs. Many authors are careful in summarizing their research findings which are inconclusive, some of them conclude that consolidations did not result in desirable effects in terms 
of relatively cheaper functioning, others point out that the differences in unit costs of small and large administrative units are insignificant. The opinions are also heard that the costs of institutional memory problems and employees' opportunism costs are significantly underestimated by the authors of reforms and, by far, exceed the achieved consolidation effects. The specific effect of "levelling up" was also noticed, i.e. both salaries and services provided by a consolidated unit present the highest level of all the constituent units. In such cases the diseconomy of scale can turn out a common phenomenon, where the functioning costs of large municipalities are significantly higher than in case of smaller ones. Many studies recognize it as the most important effect of consolidation. Thus a specific paradox takes place here, as the largest advantages are not achieved in the scope which was supposed to be the primary consolidation incentive.

\section{Conclusions}

In accordance with the new public management, taking the liberal approach to consolidation reforms in public sector is the effect of one-sided view, which narrows down an objective picture of the functioning of institutions. If the complex character of the discussed units is not taken into account, the suggested changes may not result in the assumed outcomes. The actual threat is that the rationalization measure will be focused on incorrectly identified causes. In contrast, the economies of scale achieved with structure changes are usually overestimated. The authors of the research studies presented in the article do agree that city-county consolidation reforms do not result in the assumed effects in terms of reduced functioning costs. In spite of these results, it is difficult to penetrate the well-established paradigm, that consolidation is the cure for many problems. It has the nature of the seemingly rational folk hypothesis which, however, is very difficult to support by expost research findings.

\section{References}

[1] K. Tokarczyk-Dorociak, J. Kazak, S. Szewrański, The impact of a big city on land use in suburban area - the case of Wrocław (Poland), Journal of Ecological Engineering. 19 (2018), 89-98

[2] B. Dollery, L. Crase, A. Johnson, Australian Local Government Economics, UNSW Press, Sydney, 2006.

[3] W. Kieżun, J. Kubin, Dobre państwo [Good state], Kozminski University, Warszawa, 2004.

[4] M. Kachniarz, Kooperatywność samorządów lokalnych [Cooperativeness of local governments], Research Papers of Wrocław University of Economics. 339 (2014) 36-48.

[5] K. Wollmann, Reorganizing Local Government: Between Territorial Consolidation and Twotier Intermunicipality, Croatian and Comparative Public Administration. 11(2011) 681-706.

[6] M. Kachniarz, K. Przybyła, The Impact of Administrative Reform in Central Functions of Larger Polish Cities, Journal of Economic Issues. 51 (2017) 843-862.

[7] D.C. North, Institutions, institutional change and economic performance, Cambridge University Press, Cambridge, 1994.

[8] M. Kachniarz, K. Przybyła, A. Kulczyk-Dynowska, Quality of Life in the Regional Capitals of Poland, Journal of Economic Issues. 48 (2014) 181-196.

[9] P. Swianiewicz, Reformy terytorialne - europejskie doświadczenia ostatniej dekady [Territorial reforms - European experiences of the last decade], Samorząd Terytorialny [Local Government] 6 (2015) 7-22.

[10] Z. Koudelka, Průvodce územní samosprávou po 1.1.2003, Linde, Praha, 2003. 
[11] K. Jung-Ho, P. Smith, Consolidating Local Governments and Metropolitan Governance in Korea. In: W: E. Razin, P.J. Smith (ed.), Metropolitan Governing, Canadian Cases, Comparative Lessons, The Hebrew University Magnes Press, Jerusalem, 2006.

[12] M. Byoungik, The Effect of City-County Consolidation in South Korea, The Aurburn University, Aurburn, 2013.

[13] S. Stanley, Consolidation is No Way to Streamline Government, Indiana Township Association, Fishers, 2008.

[14] M. Callanan, R. Murphy, A. Quinlivan, The Risk of Intuition: Size, Cost and Economies of Scale in Local Government, The Economic and Social Review. 3 (2014) 371-403.

[15] P. Hardy, The Consolidation of City and County Governments: A Look at the History and Outcome-Based Research of These Efforts, The University of Tennessee, Tennessee 2012.

[16] J.B. Carr, Perspectives of City-County Government Consolidation and Its Alternatives. In: J.B. Carr, R.C. Feiock (ed), City County Consolidation and Its Alternatives, M.E. Sharpe, Armonk, 2004, pp. 3-24.

[17] S. Stanley, Bigger Is Not Better: The Virtues of Decentralized Local Government, Cato Policy Analysis No. 166, Cato Institute, Washington, 1992.

[18] A.B. Brierly, Issues of Scale and Transaction Costs in City-County Consolidation, In: J.B. Carr, R.C. Feiock (ed), City County Consolidation and Its Alternatives, M.E. Sharpe, Armonk, 2004, pp. 53-86

[19] D. Durning, P. Nobbie, "Post-Transition Employee Perspectives of City-County Unification: the Case of Athens-Clark County", Public Administration Quarterly. 24 (2000) 140-168.

[20] S. Leland, K. Thurmaier, Metropolitan Consolidation Success: Returning to the Roots of Local Government Reform, Public Administration Quarterly. 24 (2000) 202-213.

[21] S. Selden, R. Campbell, The Expenditure Impacts of Unification in a Small Georgia County: A Contingency Perspective of City-County Consolidation, Public Administration Quarterly. 24 (2000) 169-201.

[22] S. White, Cooperation Not Consolidation: The Answer for Milwaukee Governance, Wisconsin Policy Research Institute Report 15, Milwaukee, 2002.

[23] F. Gamrat, H. Jake, Merging Governments: Lessons from Louisville, Indianapolis and Philadelphia, Allegheny Institute Report \#05-04, Allegheny Institute for Public Policy, Pittsburgh, 2005.

[24] Ch. Pineda, City County Consolidation and Diseconomies of Scale: Summary of Selected Literature. Ash Institute for Democratic Governance and Innovation, Harvard, 2005.

[25] J. Parr at all, Guide to Successful Local Government Collaboration in America's Regions: A Report from NLC's City Future's Program, National League of Cities, Washington, 2006.

[26] B. Cain, The Impact of City-County Consolidation on Local Government Finances, Capstone Paper, Spring 2009.

[27] M. Chisholm, Emerging realities of local government reorganization. Public Money \& Management. 30 (2010) 143-150.

[28] M. Holzer, J. Fry, Literature Review and Analysis Related to Optimal Service Delivery Arrangements and Local Government Efficiency, Rutgers, Newark, 2009. 
[29] G. Bel, Local Government Size and Efficiency in Capital - Intensive Services: What Evidence is There of Economies of Scale, Density and Scope? In: S. Lago-Peñas \& J. Martinez-Vazquez (ed.), The Challenge of Local Government Size, Edward Elgar Publishing, Northampton, 2013, pp. 148179.

[30] R. Caprio, M. Pfeiffer, Size May Not be the Issue: An Analysis of Cost of Local Government and Municipal Size in New Jersey, Local Government Research Centre, Edward J. Bloustein School of Planning and Public Policy, Rutgers University, 2014. 